\title{
Impact of coastal shrimp fishing on women and youth livelihoods and food security in Tárcoles, Costa Rica
}

\author{
Lucas Judson ${ }^{1} \&$ Vivienne Solís \\ St. Olaf College 1500 St. Olaf Ave, Northfield, MN 55057 (503)-939-015 judson@stolaf.edu
}

Received 06-VIII-2015 • Corrected 30-X-2015 • Accepted 12-XII-2015

\begin{abstract}
Fishing communities often face similar challenges that include overfishing, lack of food security, and unenforced sustainability policies. Tárcoles, mid-Pacific coast of Costa Rica, generates the majority of its income through fishing. A local cooperative aids families with direct marketing, lowering middleman power and generally benefitting the community. To understand the role of the shrimp Litopenaeus vannamei, we interviewed 47 women and youth (aged 13-72) and 41 young students (17-24) at the University of Costa Rica. We found that shrimp is a vital resource used both for food security and to improve economic situations of fishermen and women. People who have been fishing for more years perceive more positively the success of conservation efforts $(P=0,05)$. Fishermen who have fished in more recent years also perceived greater success in shrimp recuperation in the town $(P=0,03)$. At the University of Costa Rica, many students had at least a basic awareness of social and economic realities in rural fishing communities. Knowledge about artisanal fishing from UCR students was found to be very limited, with many respondents believing that artisanal fishing communities have no impact on large cities in Costa Rica. They should receive more education on this subject.
\end{abstract}

Key words: Artisanal fishing, shrimp, Tárcoles, Costa Rica, food security, livelihood.
RESUMEN: Impacto de la pesca de camarón sobre la economía y seguridad alimentaria de mujeres y jóvenes en Tárcoles, Costa Rica. La pesca excesiva, seguridad alimentaria y la falta de implementación de las políticas de sostenibilidad, son algunos de los retos que deben enfrentar las comunidades de pescadores. Tárcoles, costa media del Pacífico de Costa Rica, genera la mayor parte de sus ingresos a través de la pesca. Una cooperativa local junto con las familias se encargan de realizar el mercadeo de los productos de forma directa con el fin de reducir la participación de intermediarios y generar mayores beneficios a la comunidad. Para entender el papel del camarón Litopenaeus vannamei, entrevistamos a 47 mujeres y jóvenes (13-72 años) y 41 estudiantes (17-24 años) de la Universidad de Costa Rica. Encontramos que el camarón es un recurso vital utilizado tanto para la seguridad alimentaria y mejorar la situación económica de los pescadores y las mujeres. Las personas que han estado pescando durante más años perciben más positivamente el éxito de los esfuerzos de conservación $(P=0,05)$. Los pescadores que han pescado en años más recientes también percibieron un mayor éxito en la recuperación de camarones en la comunidad $(P=0,03)$. En la Universidad de Costa Rica, muchos estudiantes tenían al menos un conocimiento básico de las realidades sociales y económicas de las comunidades pesqueras rurales, sin embargo el conocimiento acerca de la pesca artesanal es limitada; muchos de los encuestados creen que las comunidades de pescadores artesanales no tienen impacto en las ciudades de Costa Rica. Por lo que se debe recibir más educación sobre este tema.

Palabras clave: pesca artesanal, camarón, Tárcoles, Costa Rica, seguridad alimentaria, sustento.
Tárcoles, located on the mid-Pacific coast of Costa Rica, generates the majority of its income through fishing sales. A local cooperative called CoopeTárcoles R.L aids fisherfolk families with direct marketing of fish products, lowering middleman power, bettering prices, improving working conditions, creating employment, and raising fisherfolk participation in organizations (Solís \& Madrigal, 2015).

Fishing communities globally often face similar challenges when fighting poverty and maintaining job security. Some of these include overfishing, lack of food security, and unenforced sustainability policies (Solís et al., 2015). The creation of cooperatives, associations, and marine responsible fishing areas has aided communities in their quest to overcome these challenges. By involving fishermen in the politics and design of their work through these types of work, a more fair and productive system can be achieved (McCay \& Jentoft, 1995).

To compensate for some of these challenges, the Tárcoles area has embraced a recently recognized marine responsible fishing area, which has allowed jumbo shrimp (Litopenaeus vannamei) populations to surge 
after being depleted for many years (Blanco, 2007). Shrimp, being a very lucrative product in the market, is now sought by fisherfolk to either be sold in market or to provide food security for families. Because shrimp is so profitable and has previously hovered near the brink of unsustainability, it is important that data is taken to monitor shrimp population fluctuations (Tabash-Blanco \& Chávez, 2006).

Historically, shrimp have been an exploited resource in the Gulf of Nicoya where Tárcoles borders. The golf is one of the richest fishing areas in the country, naturally providing habitat for at least 27 species of shrimp (Vargas \& Cortés, 1999). Of the total number of tropical eastern Pacific shrimp species, $43 \%$ are found on the Pacific coast of Costa Rica. During the last decade of the $20^{\text {th }}$ century, overfishing of shrimp primarily through the use of trawls caused shrimp populations to drastically diminish (Blanco, 2007). In recent years, the marine-responsible fishing area in Tárcoles has allowed shrimp populations to increase again to healthy and natural levels thanks to the agreement that trawlers must harvest in waters at least 15 meters deep to minimize damage (Cordero \& Solís, 2012).

Another way that shrimp fishing had been practiced before the marine area for responsible fishing was established had caused damage to shrimp populations by catching immature, smaller shrimp. When employing this technique, called chinchorro, the fisherman or woman would walk in the shallow water of the shore with the water reaching somewhere between their waist and their shoulders or go out in a boat. Then the fisher would begin to throw a net into the water and drag it until shrimp are caught and pulled out of the water. There is evidence that shrimp do not reproduce in the Golf of Nicoya, but catching immature shrimp may cause negative population decreases because the jumbo shrimp appear in the area before reaching reproductive capacity (Alfaro, Palacios, Aldave \& Angulo, 1993). Because this method may be able to catch more shrimp than the legal method, there is speculation that the method is still being used even in protected areas.

Artisanal fishing, however, is the smallest scale of fishing and therefore is least likely to cause environmental problems to marine species if done responsibly without the chinchorro method. In Costa Rica, semi-industrial and artisanal fishing accounts for about 35\% of total fish products (Guzmán-Mora \& Molina-Ureña, 2007). In Tárcoles, artisanal fishing is the primary source of fish harvest and has not always been recognized as a legitimate source of fish harvest by other groups of people and political entities in the country. Governmental organizations such as
INCOPESCA, and from civil society such as CoopeTárcoles, CoopeSolidar, and other regional associations and cooperatives all assist with securing the rights and prosperity of fisherfolk involved in artisan fishing.

Laws in Costa Rica have previously focused heavily on conservation of the natural environment without taking into account the social, cultural, and economic needs of the people (Fonseca \& Solís, 2005). CoopeSolidar R.L and other organizations continue to work diligently and collaboratively to compensate for these setbacks. To progress into a more peaceful and successful situation, policies and regulations that promote conservation must be changed to not only conserve natural resources, but also foment the improvement of the community wellbeing and production of culture and foster economic stability. This requires the active participation of local and indigenous communities, as well as a consensus to follow the regulations put into place (Fonseca \& Solís, 2005).

Socioeconomic issues such as accepted gender roles and poverty alleviation are important to address as well when looking at the environmental struggles of a community. The gender situation among fisherfolk families has traditionally caused men and women to engage in distinct jobs. For the most part the men control the majority of the fishing activity at sea while the women work the jobs onshore (Fløysand \& Sæther, 2007). In fishing communities, role allocation can vary depending on the personal interests of the individual as well as case-bycase demands.

The fishing communities of Costa Rica are consistently one of the most impoverished communities despite improvement of technology and organization involvement (Solís \& Madrigal, 2015). As the shrimp market opens up, this could be a way of improving the socioeconomic situation of fishing communities. The environmental success in Tárcoles has a direct effect on the socioeconomic development of the area because the increase of shrimp resources can provide more jobs and more contentment among members of the community.

One reason for the persistence of poverty in fishing communities is the disconnect between the knowledge in artisanal fishing communities and the perceptions in large, capital-producing cities. People working in cities rarely associate themselves with workers in rural areas, and this separation attributes to the continued low socioeconomic status of artisanal workers. This may be due to sheer distance and the way the culture puts more importance on corporate and industrial jobs. By increasing education efforts among youth in universities surrounding the culture and livelihood of artisanal fishermen, 
efforts to improve their socioeconomic situation are more likely to come to fruition throughout the country.

In order to reveal the social and economic impact of the shrimp resource in the town of Tárcoles, uncover knowledge about gender roles surrounding fishing and livelihoods, and determine the level of consciousness of students at the University of Costa Rica surrounding small-scale fishermen, interviews were conducted in both Tárcoles and at the UCR in San José. As part of this, it was intended to find out if shrimp was used for selling or for feeding families and its overall role in food security and economic development. Additionally, questions were asked to discover if women could acceptably fish without the presence of a man and what the role of women was in raising the next generation of fishermen. At the UCR, it was to be observed how current students view the impact of small-scale artisanal fishermen on the rest of the country and find out their overall knowledge and perceptions about the recuperation of fish resources in rural areas as a result of conservation efforts.

\section{MATERIALS AND METHODS}

Study Areas: Tárcoles, Costa Rica is a town located on the mid-Pacific coast in the Puntarenas province where practices in artisanal fishing are still a prominent aspect of the cultural identity and economic means of the people. A large portion of the population in Tárcoles participates in fishing, and more recently shrimp fishing (Solís \& Madrigal, 2015). Although it faces issues with poverty and educational opportunities, this community provides essential fish resources to food markets (Cordero \& Solís, 2012). The Golf of Nicoya, where Tárcoles is located, has been praised for its biodiversity and livelihood opportunities, although pollution from different parts of the country has begun to hurt damage some of the fish resources (Fuller et al., 1990).

The University of Costa Rica is located in the capitol city of San José, in San Pedro Montes de Oca county of San José province. This is one of the nation's public universities, and is considered one of the best universities in all of Central America. Entrance to the university is very competitive with approximately 39,000 students in attendance. Residents in the region generally have low consciousness about environmental issues in other parts of the country (Holl, Daily \& Ehrlich, 1995).

Target Populations and Procedures: Data was gathered by interviews, and oral consent was requested of respondents before participation (Digital Appendix 1).
There were 47 women/youth that were interviewed, specifically the mother of the family in most cases (Digital Appendix 2). Many of these interviews took place on the coast while working or in the houses of families. If participants wished, interviews were conducted in a space of their choosing. Some of the interview questions may have elicited information that questions traditional cultural norms, so responses were accepted without pushing for additional sensitive information.

Interviews at University of Costa Rica comprised 41 students (Digital Appendix 3) that were sitting at tables or in recreational areas of the campus. Interviews were conducted with students either alone or in groups of friends to cause minimal interruption to their schedules. Students were asked for oral consent and only participated if they felt comfortable doing so. Methods of protection of human research subjects and interview methodology was approved by the ACM (Associated Colleges of the Midwest) Ethics Panel.

Data Analysis: Difference in mean response of perception of shrimp recovery between parents in favor or not in favor of children becoming fishermen was estimated with a parametric, one-way ANOVA. Homogeneity of variance was tested and complied with an a posteriori comparisons of means used Least Significant Difference $95 \%$ confidence intervals. Strength of relationships of perception of shrimp recovery with the years of fshing experience and the recentness of fishing were estimated with simple, parametric regression. Strength of relationship of favorability index to fishing with perception of shrimp recovery was estimated with simple, parametric regression. Best fitting models were selected. Statistical testing was completed with Statgraphics Centurion XVI computer package (Statpoint Technologies, Inc., www. statgraphics.com/ statpoint.htm) and statistical procedures followed Sokal and Rohlf (1995).

\section{RESULTS}

Of the 47 people interviewed in Tárcoles, 9 were men and 38 were women; 18 of the 47 interviewed were youths, defined as being 25 years old or younger. The ages spanned from 13 to 72 years old (Digital Appendix 4). A total of 19 out of the 47 interviewed consider themselves regular fishermen. Of the 41 students interviewed at the University of Costa Rica, 25 were men and 16 were women. The ages spanned from 17 to 24 years old (Digital Appendix 5). 


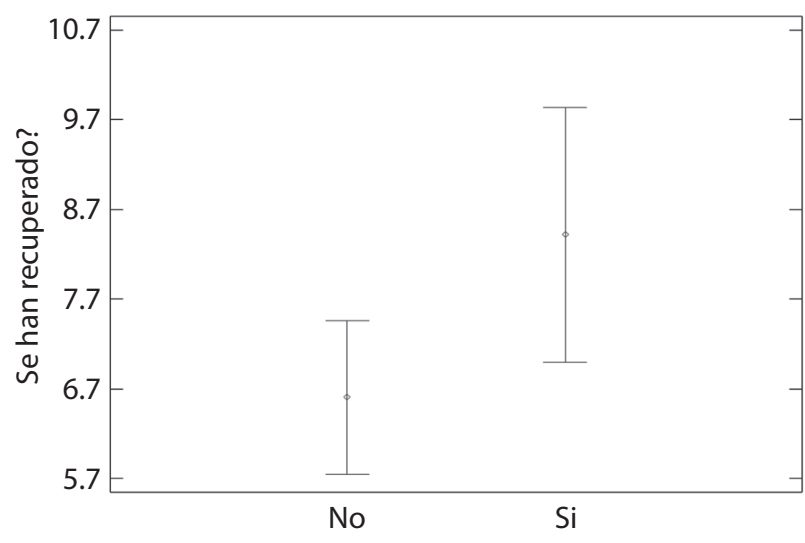

Fig. 1. Mean response of parents' perception of shrimp recovery between favoring or not children to become fishermen. Vertical lines \pm 1 Least Significant Difference 95\% confidence intervals.

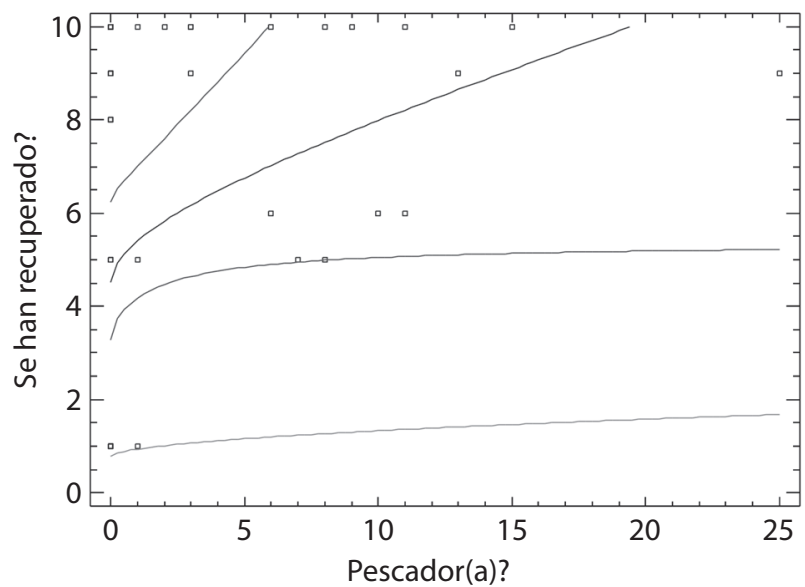

Fig. 2. Relationship of perception of shrimp recovery to years of being an active fisherman.

Mean response of perception of shrimp recovery in the protected marine areas was greater for those Tárcoles respondents that wanted their children to be fisherman $(\bar{X}=8.41)$ compared to those who didn't ( $\bar{X}=6.6 ; F=2.43$; $d f=1.43 ; P=0.12 ;$ Fig. 1). A strong positive relationship showed the longer a Tárcoles fisherman or woman has fished, the more they believed shrimp resources have recovered $(F=4.04 ; d f=1,43 ; P=0.05 ;$ Fig. 2 ). Another strong, positive relationship showed that Tárcoles women who have fished more recently (this year or in the last 5 yrs) had a perception of greater shrimp recovery than those that no longer fish (more than 5 yrs ago or never)( $F=4.91$; $\mathrm{df}=1,34 ; \mathrm{P}=0.03$; Fig. 3). Those in Tárcoles who thought that more shrimp had recuperated did not necessarily like to fish more than those who thought less shrimp had recuperated ( $F=1.29 ; d f=1,34 ; P=0.26$; Fig. 4).

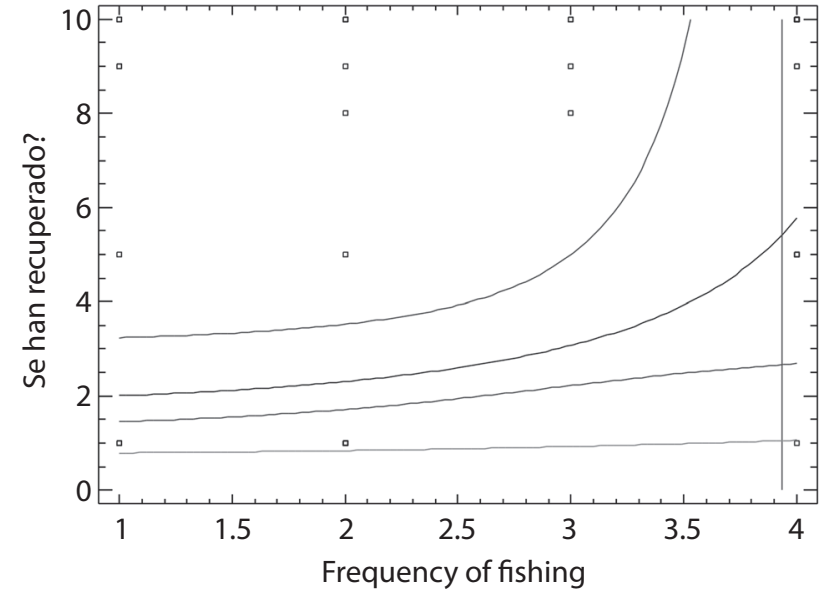

Fig. 3. Relationship of perception of shrimp recovery to frequency of fishing.

Plot of Fitted Model

Le gusta \# = sqrt (3.13206 + 1.72497 / Se han recuperado?)

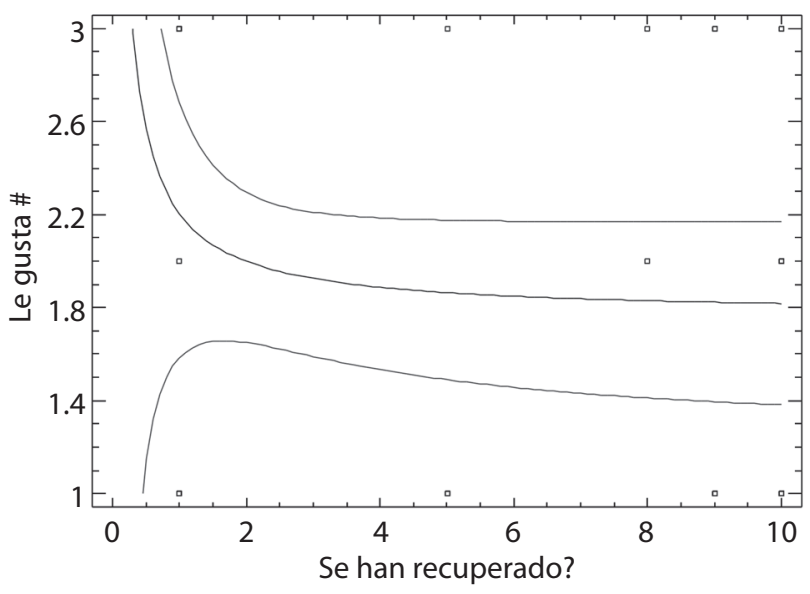

Fig. 4. Relationship of favorability ( $1=$ does not like to fish, $3=$ loves to fish) to fishing scale with perception of shrimp recovery.

When asked about jumbo shrimp as an important resource for the community, $100 \%$ of Tárcoles women and youth said yes. Additionally, $91.5 \%$ of Tárcoles women agreed that the shrimp resource has helped them economically. When asked about the shrimp resource in Tárcoles having helped women and youth with food security, $89.4 \%$ testified that it had (Digital Appendix 6). Shrimp was found to be a vital economic resource as $100 \%$ of Tárcoles youth and $93.6 \%$ of total Tárcoles respondents (women and youth) claimed that they sell at least a portion of the shrimp that they catch. 
While $100 \%$ of Tárcoles respondents said that they are happy and feel comfortable in the community as a woman or youth, only $25.5 \%$ of all Tárcoles respondents said that they would like for their children to become fishermen. Despite not wanting their children to fish, only $14.9 \%$ of Tárcoles women and youth did not like to fish in the community of Tárcoles.

Only $6.3 \%$ of Tárcoles women and youth fished without the company of a man, but $48.9 \%$ of Tárcoles respondents said that both women and men help teach the children in the community how to fish (Digital Appendix 7). At the UCR, $61 \%$ of respondents believed that there are different gender roles between men and women in artisanal fishing communities, $73.2 \%$ of UCR respondents do not actually know anyone who is a fisherman.

The majority of students (56.1\%) claimed that artisanal fishermen have no impact on larger cities. The next largest portion (39\%) said that there is actually a positive impact, while $4.8 \%$ of students described a negative impact by artisanal fishermen on larger cities.

Over half of UCR respondents $(56.1 \%)$ said that no shrimp has recovered since the establishment of the responsible fishing area. The other portion of students either had little knowledge about the area or believed that some had recuperated.

Though none of the UCR students are fishermen, $53.7 \%$ have fished, and of those that have fished, $63.6 \%$ like to fish. Only $9.1 \%$ of those who have fished have participated in artisanal fishing. With very little knowledge overall about the fishing situation, a total of $97.5 \%$ of UCR respondents do not want their children to be fishermen.

\section{DISCUSSION}

Importance of Shrimp in Tárcoles: The Pacific coast of Costa Rica is home to an abundance of biodiversity from the northern region of Guanacaste down to the southern tip of the Puntarenas province. The town of Tárcoles, located in the outer part of the Gulf of Nicoya, has stood out as one of the most prosperous fishing communities with regards to culture and fishing success (Blanco, 2007). Unfortunately, because of the overfishing, improper fishing techniques, and external factors such as pollution of the marine environment, some of the fish supplies had been depleted, including the entire supply of jumbo shrimp. In response to this, the marine area for responsible fishing was established as a request to the state by the fishermen in order to enforce sustainable fishing techniques (Fonseca \& Solís, 2005). Since the establishment of this area, the jumbo shrimp have returned to the shore and can be sustainably fished by members of the community.

As the shrimp resource has come back in earnest, the community has begun to depend on it as a source of food and of income again. Although everyone in the community that participated in this study recognized the importance of shrimp, some still believe that the resource has not recuperated much at all. While there are some years where shrimp yields are lower (perhaps as a result of climate change or the El Niño effect), there simply was no shrimp at all before the establishment of the responsible fishing area. Curiously, through everyday conversation it was observed that even some of the older generation has expressed negativity toward the protected marine area despite having lived through the period when there were no shrimp in the shore area. The previous knowledge of depleted resources seems to have been forgotten or neglected by many, causing a lack of appreciation for what has been recuperated. One reason for this could be because of the overall inconsistency of fish resources for fishermen in general; based on the climate or ocean patterns of each particular year, more or less fish and shrimp of various species may or may not return to the shores (Perry, Low, Ellis \& Reynolds, 2005). Regardless of why some fishermen believe that the resource has yet to recover, there is a consensus that shrimp holds incredible value for everyone in Tárcoles.

Shrimp is an important resource to Tárcoles because it is one of the most lucrative and tasty marine products from the region. Most of the fishermen have explained that the shrimp only appear in the Tárcoles marine area during the summer months, with generally high populations between February and April. Therefore fishermen and women have to find other sources of food and income during other months of the year. This is tough for many people who depend on the shrimp resource for economic support and for recreational enjoyment. Because of its high price, most women and youth decide to sell most if not all of their catch (Keefe\& Jolly, 2000). However, some women choose to bring shrimp to the house to feed their families often times in addition to selling some of the day's catch. The grand majority said that shrimp fishing has helped either themselves personally or the community as a whole in terms of economic development and food security. This result speaks greatly to the vital importance of shrimp in sustaining the wellbeing of individual families and of the community as a whole.

Role of Women: This moment in history represents a transition in women's roles in fishing communities such as Tárcoles. Previously, men and women inhabited fixed 
gender roles: the men went out to fish and the women cared for the house and children (Fløysand \& Sæther, 2007). The public sphere belonged to the men and the private sphere belonged to the women. Now, as women transition into parts of the public sphere, the duties and pressures of women have greatly increased. The transition into being able to fish with the men or with other women has not alleviated any traditional responsibilities, but rather has only added more work to each day. While it is more acceptable for women to fish and collect shellfish on the shores, these women are still in charge of taking care of the house and the children the same as before. Being in this transition state puts a lot of pressure and stress on women as they try to balance their home life and their work life.

Women also play an important role in teaching the younger generation how to fish. About half of respondents in Tárcoles said that a woman might take part in teaching shrimp techniques and methods to new fishermen and women. This puts women in an important role as contributors to the fishing culture that dominates in Tárcoles. However, very few women seem to participate in fishing activities without the help of a man. This does not invalidate their importance but rather shows that both genders are necessary for the continuance of the fishing culture (Fløysand \& Sæther, 2007).

Happiness and Wellbeing: When asked about their overall comfort and feelings about their role as a woman or youth in the community, every single respondent said that they feel good and accepted. Although life is difficult for a fisherman or woman and income is low for nearly everybody, the people are happy, safe, and respected by one another. Additionally, the vast majority of the people in Tárcoles enjoys fishing and finds that it gives their life value. Despite the importance of fishing, many fishermen are opting to work in other careers because of both the danger of fishing and the instability of its income (Davis, 2012). This is an unfortunate reality for many workers in Tárcoles, because they truly do love to fish.

Impact of Artisanal Fishing On Large Cities: Based on the respondents' interview answers, there is a clear disconnect in knowledge and understanding of current situations between the larger cities and rural fishing communities. Over half of UCR respondents said that artisanal fishing communities have no impact on cities such as San José, which shows that many do not know where their fish supplies come from. This ignorance of the importance of artisanal fishing communities on city-dwellers can cause a number of problems relating to policy and socioeconomic class relations (Clay \& Olson, 2007).
Most important policy decisions are created and carried out in large cities such as San José. If there is a lack of interest and knowledge about the rural fishing communities and their importance for the rest of the country, politicians run the risk of making policies that do not provide maximum benefit to rural communities or the country as a whole (Clay). The effects of this can include insufficient resources, unrealistically intense or too relaxed fishing restrictions, and issues with discrimination and prejudice. Therefore, it is unfortunate that many students believe that there is no connection between their communities and that of the rural fishing community, and it is imperative that education efforts shift to include more awareness of the rural areas of the country.

Perceptions of UCR Students on Artisanal Fishing: Through conversation with students at the UCR, it is clear that there is a cultural belief that certain careers are more prestigious and more valued than others. Near the bottom of this hierarchy is the occupation of fisherman. It is due to this that many students find fishing communities a topic that is unworthy of study for their specific career paths. Also related to this point is that all but one respondent at the UCR did not want their children to be fishermen. It is evident that fishermen are perceived as poor, lower class, disconnected people. Although it is true that fishermen occupy one of the poorest classes of society, this negative outlook on the profession is also potentially problematic when establishing good relations and just policies for those in fishing communities such as Tárcoles (Salagrama, 2006).

Regarding the role of women in small-scale fishing communities, over half of UCR respondents said that there is no difference in the gender role between women and men. This was astonishing discover because it is commonly thought that rural areas have stronger traditions whether it be in celebrations, marriage and family rituals, or gendered work (Deb, Haque \& Thompson, 2015). Large cities in Costa Rica still show evidence of difference in gender roles, so the obvious assumption would be that the roles are even stronger in the rural areas. However, many did not respond this way, and thought that men and women shared equal work. This perception is mostly incorrect, as fishing is still heavily male dominated and very few men participate in household chores and duties in communities like Tárcoles. However, the attitude is optimistic because it shows that people believe that gender roles can change and equalize as time goes on. Unfortunately, while women are slowly gaining more ground in the public sphere, traditional values and machismo continues to play a role in their limited ability to explore their calling outside the household. 
Culture and the Environment: Culture and environment are strongly connected, and a shift in either way can cause a tangible shift in the other. In the case of Tárcoles, there is a persistent culture of illegal shrimp fishing practice that makes it difficult to uphold the restrictions put into place by the marine area for responsible fishing as well as improve the amount of shrimp population recuperated. In order to ensure that the jumbo shrimp resource is fully recovered and maintained, a cultural shift must take place to put sustainable fishing as a priority. Only with a widespread acceptance and voluntary dedication to fish sustainably can the natural resource be protected (Cordero \& Solís, 2012). This outcome is difficult to achieve partly because of tradition, but also because of economic limitations. Some women and youths that fish in Tárcoles reported to me that they do not have the economic capabilities to purchase the necessary boat and equipment to fish for shrimp in the legal way. Therefore, economic subsidies may be in the community's best interest to encourage legal practice.

The cultural differences between San José and communities like Tárcoles also cause a negative environmental impact. Those who live in the large cities do not often feel that they are connected culturally with those in rural areas, and this results in a detrimental indifference that negatively affects rural communities. One manifestation of this is the pollution that flows from the Central Valley Provinces (San Jose, Heredia, Alajuela and Cartago) to the mouth of the Tárcoles River just a few meters from the town of Tárcoles (Fuller). This influx of waste has caused problems with biodiversity and water cleanliness and accessibility in Tárcoles and neighboring communities. In order to combat this, San José and other large cities must see themselves as connected to rural fishing towns and recognize their continued existence as vital to the country as a whole.

The renewed shrimp resource is vital for economic and food security in Tárcoles and women play an important role in fishing in addition to other jobs in the community. With more shrimp resources in sea, women can also extend further into the public sphere and help support their families economically and with food security. Many families want their children to study and find a more stable job than fishing. By focusing on natural resource conservation, issues with poverty can be improved as more work becomes available. Most urban-dwelling students know very little about artisanal fishing in their country, and most do not want their children to be fishermen.

\section{ACKNOWLEDGEMENTS}

I also thank my two host families, in San José and in Tárcoles for supporting me and allowing me to live in their homes. Lastly, I want to thank Michael McCoy for helping edit drafts and teaching important research techniques that I used during my data collection and analysis.

\section{REFERENCES}

Alfaro, J., Palacios, J., Aldave, T., \& Angulo, R. (1993). Reproducción del camarón Penaeus occidentalis (Decapoda: Penaeidae) en el Golfo de Nicoya, Costa Rica.Rev. Biol. Trop., 41(3), 563-572.

Blanco, F. T. (2007). Explotación de la pesquera de arrastre de camarón durante el periodo 1991-1999 en el Golfo de Nicoya, Costa Rica. Rev. Biol. Trop, 55(1), 207-218.

Clay, P. M., \& Olson, J. (2007). Defining Fishing Communities: Issues in Theory and Practice. National Association for The Practice of Anthropology Bulletin, 28, 27-42. doi:10.1525/napa.2007.28.1.27

Cordero, P., \& Solís, V. (2012). Recognition and support of ICCAs in Costa Rica. Global overview and national case studies, 1-33.

Davis, M. E. (2012). Perceptions of occupational risk by US commercial fishermen.Marine Policy, 36(1), 28-33.

Deb, A., Haque, C., \& Thompson, S. (2015). 'Man can't give birth, woman can't fish': gender dynamics in the small-scale fisheries of Bangladesh. Gender, Place, \& Culture, 22(3), 305-324.

Fløysand, A. \& Sæther, A. (2007). Globalización, comunidades pesqueras y construcción de género: el caso de muros (Galicia). Boletín de A.G.E, 45, 31-48.

Fonseca, M. \& Solís, V. (2005). Pesca artesanal y participación en conservación de recursos de marino-costeros. Ambientales, 44-51.

Fuller, C., Davis, J., Cain, D., Lamothe, P., Fries, T., Fernandez, G., ... Murillo, M. (1990). Distribution and transport of sediment-bound metal contaminants in the rio grande de tarcoles, costa rica (Central America). Water Research, 24(7), 805-812. doi:10.1016/0043-1354(90)90130-X

Guzmán-Mora, A. G. \& Molina-Ureña, H. (2007). La pesquería artesanal de peces en Golfo Dulce, Costa Rica. La Escuela de Biología, Universidad de Costa Rica, 137-142.

Holl, K. D., Daily, G. C. \& Ehrlich, P. R. (1995). Knowledge and Perceptions in Costa Rica Regarding Environment, Population, and Biodiversity Issues. Conservation Biology, 9(6), 1548-1558. 
Keefe, A., \& Jolly, C. (2000). Price flexibility and change in international shrimp supply.Aquaculture Magazine, 26(4), 26-35.

McCay, B., \& Jentoft, S. (1995). User participation in fisheries management: lessons drawn from international experiences. Marine Policy, 19(3), 227-246.

Perry, A. L., Low, P. J., Ellis, J. R., \& Reynolds, J. D. (2005). Climate Change and Distribution Shifts in Marine Fishes. Science, 308(5730), 1912-1915. doi:10.1126/science.1111322

Salagrama, V. (2006). Trends in poverty and livelihoods in coastal fishing communities of Orissa State, India. FAO fisheries technical paper, 490, 1-111.
Sokal, R. R. \& Rohlf, F. J. (1995). Biometry: the Principles and Practice of Statistics in Biological Research.

Solís, V. \& Madrigal, P. (2015). Institutions and collective action in small-scale fisheries: the case of CoopeTárcoles R.L. Costa Rica. Food and Agriculture Organization of the United Nations (FAO), 1-74.

Vargas, R., \& Cortés, J. (1999). Biodiversidad marina de Costa Rica: Crustacea: Decapoda (Penaeoidea, Sergestoidea, Caridea, Astacidea, Thalassinidea, Palinura) del Pacífico. Rev. Biol. Trop, 47(4), 887-911.

Tabash-Blanco, F.A., Chávez, E.A. (2006). Optimizing harvesting strategies of the white shrimp fishery in the Gulf of Nicoya, Costa Rica. Crustaceana 79(3): 327-343.

\section{SEE DIGITAL APPENDIX}

